\title{
APOPTOSIS IN ACUTE KIDNEY INJURY
}

\author{
Marilena Stoian¹, Ana Maria Dumitrache², Fivi Cîrciu², Roxana Stănică², Victor Stoica1,2 \\ "Carol Davila" University of Medicine and Pharmacy \\ 2"Dr. Ion Cantacuzino" Clinical Hospital, Bucharest \\ Correspondence to: Marilena Stoian, MD,PhD., 65, Matei Basarab Street, L109, sc 2, ap 27. \\ District 2, P.O. 030675, Bucharest, Romania \\ E-mail: marilenastoian@yahoo.com
}

\begin{abstract}
Apoptosis is an inborn process that has been preserved during evolution; it allows the cells to systematically inactivate, destroy and dispose of their own components thus leading to their death. This program can be activated by both intra and extracellular mechanisms. The intracellular components involve a genetically defined development program while the extracellular aspects regard endogenous proteins, cytokines and hormones as well as xenobiotics, radiations, oxidative stress and hypoxia. The ability of a cell to enter apoptosis as a response to a "death" signal depends on its proliferative status, the position in the cell cycle and also on the controlled expression of those genes that have the capacity of promoting and inhibiting cell death. The fine regulation of these parameters needs to be maintained in order to ensure the physiological environment required for the induction of apoptosis.

In this review, we first describe evidence for the role of apoptotic pathways in ischemic acute renal failure, and then consider the potential mechanisms that may participate in this model of acute renal tubular injury. Potential therapeutic interventions to prevent tubular apoptosis in renal disease include angiotensin system inhibition, whereby the angiotensin II AT2 receptor blockade seems more promising in apoptosis inhibition than the inhibition of other receptor subtypes. A better understanding of the mechanisms of apoptosis could lead to safer and more specific therapeutic interventions for acute kidney injury.
\end{abstract}

Keywords: acute kidney injury, apoptosis, necrosis, ischaemia reperfusion, toxic renal injury.

\section{Rezumat}

Apoptoza este un proces înnăscut care s-a păstrat pe parcursul evoluției; permite celulelor să inactiveze, să distrugă și să elimine sistematic propriile componente, cauzându-și astfel moartea. Acest program poate fi activat atât prin mecanisme intra, cât și extracelulare. Componentele intracelulare implică un program de dezvoltare determinat genetic, în timp ce 


\section{INTERNAL}

\section{General Reviews}

aspectele extracelulare privesc proteine endogene, citokine și hormoni, precum și xenobiotice, radiații, stres oxidativ și hipoxie. Capacitatea unei celule de a intra în apoptoză ca răspuns la un semnal de "moarte" depinde de statusul său proliferativ, de poziția în ciclul celular și, de asemenea, de expresia controlată a genelor care au capacitatea de a promova și inhiba moartea celulară. Pentru a asigura mediul fiziologic necesar pentru inducerea apoptozei, trebuie menținută reglarea fină a acestor parametri.

În această lucrare, prezentăm dovezi cu privire la rolul căilor apoptotice în insuficiența renală acută ischemică și apoi luăm în considerare mecanismele potențiale care ar putea participa la acest model de leziune tubulară renală acută. Intervențiile terapeutice potențiale pentru prevenirea apoptozei tubulare în boala renală includ inhibarea sistemului angiotensină; în acest sens, blocarea receptorului de angiotensină II AT2 pare mai promițătoare în inhibarea apoptozei decât inhibarea altor subtipuri de receptori. O mai bună înțelegere a mecanismelor apoptozei ar puatea conduce la intervenții terapeutice mai sigure și mai specifice pentru injuria renală acută.

Cuvinte cheie: leziunea renală acută, apoptoză, necroză, reperfuzia ischemiei, leziune renală toxică.

\section{Introduction}

Apoptosis or programmed cell death is essential for the development and for the well functioning of multicellular systems. In order to ensure functional and structural tissue homeostasis non-necessary and deteriorated cells have to be removed from an otherwise healthy cellular microclimate. Examples of apoptosis have been observed in almost all cellular types during their development and maturation. Throughout embrionic life the genesis of cells and organs is supervised by a genetically controlled programme which involves cell proliferation and apoptosis.

In adult tissues physiological cell death appears in cyclic stimulated tissues or hormonally dependent tissues like the endometrium, the prostate or the mammary gland but also in the steady-state turnover of many other tissues. Selective cell death is fundamental for the development, regulation and for the well functioning of the immune system including the elimination of auto-reactive thymocytes, the negative 
selection of $\mathrm{T}$ and $\mathrm{B}$ lymphocytes and also for the cellular death induced by cytotoxic $T$ lymphocytes. Endogenous processes that have the capacity of detecting irreparable genetic deteriorations are involved in the process of limiting the dissemination of these abnormalities. The lymphocytes invading immunologically "privileged" tissues are rapidly eliminated thus offering protection from a possible inflammatory response in these special ${ }^{(1)}$. Nowdays the unified concept behind all of these processes is that apoptosis is mediated by a common set of events and it uses similar biochemical pathways leading to a stereotypic disposition of the structural alterations.

Apoptosis is an inborn process that has been preserved during evolution; it allows the cells to systematically inactivate, destroy and dispose of their own components thus leading to their death. This programme can be activated by both intra and extracellular mechanisms.

The intracellular components involve a genetically defined development programme while the extracellular aspects regard endogenous proteins, cytokines and hormones as well as xenobiotics, radiations, oxidative stress and hypoxia. The ability of a cell to enter apoptosis as a response to a "death" signal depends on its proliferative status, the position in the cell cycle and also on the controlled expression of those genes that have the capacity of promoting and inhibiting cell death. The fine regulation of these parameters needs to be maintained in order to ensure the physiological environment required for the induction of apoptosis. Any malfunction in any one of the steps of controlled cellular death can lead to disfunctions and as a consequence to different pathological conditions

The importance of apoptosis lies in its active nature and in the potential of controlling biological systems.

Cellular death has been considered a chaotic process. Nevertheless just as a single cell can balance between anabolic and catabolic states the entire organism needs to balance the proliferation and cell death states in order to ensure homeostasis All the more an organism needs to dispose of aged, deteriorated or abnormal cells that have the potential for malignant transformation. As such the changes that may appear in the regulation of apoptosis could contribute to the pathogenesis of degenerative and neoplastic diseases. Although physiological cell death has been described for many decades, the problem has been put forward again in the seventies when Kerr, Wyllie and Currie have described in detail the infrastructural changes characteristic of dying cells and have also proposed the term apoptosis to define this process. They have showed that physiological cell death is not a random process but a process that possesses distinct morphological features. It usually affects individual cells and once initiated it evolves rapidly.

The ingestion of apoptotic cells by macrophages does not induce the release of proteolitic enzymes or active oxygen species by the latter cells. The fragmenting of the dying cells takes place without an extracellular leak of their contents and the removal of these cells does not induce inflammation. The absence of inflammation represents a crucial feature of apoptosis thus allowing cell death without an alteration of the adjacent structures.

\section{Apoptosis versus necrosis}

It has been generally accepted that a catastrophic breakdown of regulated cellular 


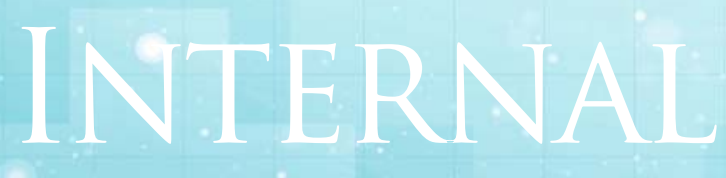

\section{General Reviews}

homeostasis, known as necrosis, is the mode of cellular injury in various forms of acute renal failure. One of the major advances in our understanding of cell death has been the recognition that the pathways traditionally associated with apoptosis as described in the landmark study by Kerr, Wyllie, and Currie in $1972^{(2)}$ may be very critical in the form of cell injury associated with necrosis. The pathway that is followed by the cell varies with both nature and severity of insults and may evolve from an apoptotic to a necrotic form of cell death. It is also likely that there are some common pathways that are shared and regulated in the two modes of cell death (Figure 1).

\section{Genetics and apoptosis}

Despite numerous research advances it is still very difficult to identify all of the molecules involved in the apoptosis process in mamalian organisms. Fortunately the nematode Caenorhabditis elegans represents a particularly useful study model of the genetic regulation of apoptosis ${ }^{(3)}$. Throughout the embrionic and larval stage of its development a number of 131 of a total of 1090 cells are being eliminated following a very constant and well characterized genetic programme. Thus a large number of mutations has been identified and the responsible genes have been ordered to form a genetic map. These genes are involved in the decision to enter apoptosis, in incorporating dying cells in mononuclear cells, in the execution of this process and in degrading the cellular debris. Two of these genes, ced-3 and ced-4 are necessary in order for all forms of apoptosis to occur and it is thought that they encode the final effectors of this path Another regulatory key gene, ced-9,is involved in suppressing apoptosis in those cells that are preprogrammed to live ${ }^{(4)}$ This gene encodes a protein that is homologous to the $\mathrm{BCl}-2$ gene from humans.

Moreover the expression of $\mathrm{BCl}-2$ can inhibit apoptosis in nematodes and can even partially substitute for the loss of function of Ced-9, indicating that at least some parts of the apoptosis have been conserved during evolution. There are mutations appearing in six genes that are responsible for the uploading of apoptotic bodies into non professional "neighbor" cells. Intracellular proteins like Ced-2, Ced-5 and Ced-10 use signaling pathways similar to those of other mamalian homologues like CrkIl, DOCK 180 and Rac thus modulating cytoskeleton's reorganisation and extension in the encorporating cell. Ced-7, homologous to $A B C-1$ is activated in both the apoptotic cell and in the macrophages. Ced-1 is analogue to the scavenger receptors in the mamalian system; Ced-7 and Ced-1 are probably 


\begin{tabular}{|l|l|}
\hline Apoptosis & Necrosis \\
\hline $\begin{array}{l}\text { Programmed death of unwanted cells } \\
\text { (loss of growth stimuli) }\end{array}$ & $\begin{array}{l}\text { Accidental, unplanned severe injury } \\
\text { (toxins, ischaemia ) }\end{array}$ \\
\hline & \\
\hline Hours (12-18) & Minutes \\
\hline Individual cells & \\
\hline Intact membrane . & Adjacent areas \\
\hline Nuclear condensation. & Necrosis, plasma membrane disruption \\
\hline Cell shrinkage & Cytoplasm and cell volume \\
\hline Blocking of cell surface & Organelles swell \\
\hline Cell fragmentation & \\
\hline Organelles retain integrity & \\
\hline & \\
\hline Suicide Murder & Lysis \\
\hline Needs energy . & Murder \\
\hline Activation of enzymes (endonucleases) & Loss of enzyme \\
\hline Save removal by phagocytes & Leakage-inflammation \\
\hline No inflammation & \\
\hline & \\
\hline
\end{tabular}

Figure 1. Apoptosis versus necrosis (adapted from ${ }^{(2)}$ ) 


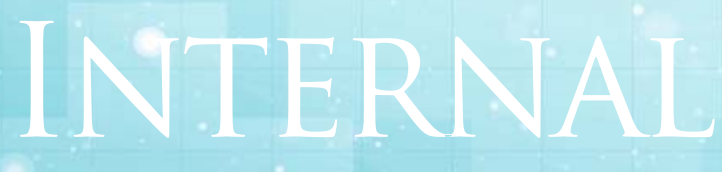

General Reviews

involved in promoting the uploading process through their interaction with the signaling adaptor protein Ced-6 ${ }^{(5)}$.

There are 14 different genes that suffer mutations affecting apoptosis at different levels. Only a small number of genes are affected by mutations influencing the decision to enter the cell death process. The next steps are similar to those seen in any somatic cell engaged in apoptosis. The activation of ced-3 and ced-4 promotes cell death while ced-9 is able to prevent this process.

Apoptosis of renal tubular epithelial cells plays a major role in acute renal failure. Several external and internal signals can induce apoptosis, which is then effectuated via several pathways. These pathways are either the FAS/FAS-L pathway and downstream MAPK (mitogen-activated protein kinases) and JNK (c-Jun N-terminal kinase) signal transduction, or the RANK/RANK-L (receptor activator of NFkB) pathway via activation of the caspase cascade. Other pathways, especially for apoptosis induction by toxins, include the mitochondrial permeability transition pore activation and $\mathrm{Bcl}-2$ superfamily member differential regulation. An important final, irreversible branch of these pathways is the release of cytochrome $c$ from the mitochondria, leading to nuclear fragmentation. Therapeutic interventions of acute tubular injury focus on the prevention of apoptosis by either modulation of the balance of the bcl-2 family or by selectively blocking angiotensin receptors. It is not clear yet, which receptor blockade or combination of receptor blockers is most effective in apoptosis prevention. In chronic renal failure, tubular apoptosis has been found in biopsies from polycystic kidneys, but not in a quantitatively meaningful amount in other chronic human renal diseases. On the other hand, given the short half-life of apoptotic cells of few hours, even low numbers over time might turn out to be important modulators of chronic kidney disease, which are characterized by tubular cell loss. Potential therapeutic interventions to prevent tubular apoptosis in chronic renal disease include angiotensin system inhibition, whereby the angiotensin II AT2 receptor blockade seems more promising in apoptosis inhibition than the inhibition of other receptor subtypes.

\section{Apoptosis in ischaemia reperfusion and toxic renal injury}

Acute kidney injury (AKI) in the critical care setting is defined as the abrupt decline in glomerular filtration rate (GFR) resulting from ischemic or toxic injury to the kidney. AKI is often only one of several organ-system failures that are present in this patient 
population. Recent evidence suggests that there are four major factors that are the most important in the initiation and maintenance of AKI. These include a decrease of glomerular capillary permeability, back-leak of glomerular filtrate, tubular obstruction, and intrarenal vasoconstriction. Both sublethal and lethal cell injury have been found in $\mathrm{AKI}$, with the latter related either to necrosis or apoptosis.

Intrarenal vasoconstriction, related to a shift in the balance between endothelin and endothelium-derived nitric oxide, is receiving considerable attention as a major contributor to the pathogenesis of AKI, with therapeutic manoeuvres targeted at restoring the usual balance, and relieving intrarenal vasoconstriction. If such approaches prove to be of value, the outcome of patients with this serious condition might be substantially improved.

Acute kidney injury (AKI) is a common renal disease affecting up to $5 \%$ of all hospitalized patients, with a higher prevalence of $10-30 \%$ in patients in critical care units. Despite advances in the management of critically ill patients and technological advances in renal replacement therapy, the high mortality of patients with AKI has not changed over the last decades and remains above 50\%. Moreover, as a consequence of more advanced medical therapy and more complicated surgical interventions in older and multimorbid patients, the number of patients with AKI is increasing.

Moreover, AKI itself increases the risk to develop additional complications that can be deleterious. Recently, an independent association between $\mathrm{AKI}$ and mortality has been shown in patients following administration of radiocontrast media in an intensive care unit and in patients following cardiac surgery. Following radiocontrast media the mortality of patients with AKI was increased five fold and following cardiac surgery sixteen-fold as compared to patients with the same underlying disease without AKI. The pathophysiology of ischemic AKI is reviewed with the emphasis on the following mechanisms:

1. Increased fractional excretion of sodium;

2. Activation of tubulo-glomerular feedback;

3. Cytoskeleton disruption;

4. Tubular obstruction;

5. Vascular mechanisms.

The following mediators will also be discussed:

- Calcium;

- Cysteine proteases;

- Nitric oxide;

- Adhesion receptors and integrins.

Renal tubular cells that are lethally injured after an acute ischemic or nephrotoxic insult to the kidney can die by necrosis or apoptosis. Necrosis is usually the result of overwhelming and severe cellular ATP depletion. In contrast, there are many potential causes of apoptosis in acute acute kidney injury (AKI) .These include cytotoxic events not severe enough to induce necrosis, a relative deficiency of renal growth factors, and loss of cell-matrix or cellcell adhesive interactions. In some situations, receptor-mediated events induced by tumor necrosis factor-alpha (TNF-alpha) or Fas (CD95) may play a role in apoptosis in AKI. Necrosis and apoptosis are distinct morphologically and biochemically. Necrosis results in an early loss of plasma membrane integrity, the release of injurious substances from the cytosol, and an inflammatory reaction in the surrounding tissue that is readily detected morphologically. In contrast, 


\section{INTERNAI}

\section{General Reviews}

apoptosis is characterized by progressive cell shrinkage with condensation and fragmentation of nuclear chromatin. Apoptotic cells ultimately break up into plasma membrane-bound vesicles called "apoptotic bodies" that are rapidly phagocytosed by macrophages and neighboring epithelial cells. In experimental models of AKI in vivo, apoptosis of renal tubular cells has been shown to occur in two distinct phases ${ }^{(6)}$. The first phase of apoptosis occurs early on, between 12 and 48 hours after the acute ischemic or nephrotoxic insult. The second phase of apoptosis occurs many days later, during the recovery phase of AKI. Tubular cell apoptosis occurring shortly after the acute insult probably contributes to tubular cell loss and the tubular dysfunction associated with AKI. In contrast, the apoptosis associated with the recovery phase has been postulated to contribute to the remodelling of injured tubules and to facilitate their return to a normal structural and functional state. Therapeutic interventions that inhibit or promote apoptosis of renal tubular cells have the potential for minimizing renal dysfunction and accelerating recovery after AKI.

\section{Therapeutic implications}

The inhibition of apoptosis may be undesirable such as apoptotic death of cells by chemotherapeutic agents with irreparable
DNA damage. It is not clear that apoptotic death induced in response to mild ischaemic or toxic injury serves any useful 'homeostatic role'. The observations of Marc E.De Broe in a toxic model of acute renal injury seem to support a role of apoptosis in the remodeling of the proliferative regenerating proximal and hyperplastic hypertrophic distal tubule ${ }^{(7)}$. The potent prosurvival effect of anti-apoptotic $\mathrm{Bcl}-2$ family member proteins, the activity of the transcription factor $N F \& B$ and the upstream signalling kinase pathways represent the three areas for pharmacological intervention ${ }^{(8)}$. In addition, during the early execution phase the caspase system can be modulated, using cell permanent inhibitors. They have been shown to prevent tubular cell death in response to ischaemic injury ${ }^{(9)}$ is clear that more insights into the events involved in apoptosis are needed before therapeutic agents interfering with this system can be used.

Potential therapeutic interventions to prevent tubular apoptosis in chronic renal disease include angiotensin system inhibition, whereby the angiotensin II AT2 receptor blockade seems more promising in apoptosis inhibition than the inhibition of other receptor subtypes.

A better understanding of the mechanisms of apoptosis could lead to safer and more specific therapeutic interventions for acute renal failure. 


\section{References}

1. Griffith T.S., Brunner T., Fletcher S.M., Green D.R., Ferguson T.A., Science, 2005, 267, 1189-1192

2. Kerr JFR, Wyllie AH, Currie AR. Apoptosis: a basic biological phenomenon with wide-ranging implications in tissue kinetics.BrJ Cancer 1972; 26: 239-257

3. Steller, Science, 2015, 267, 1445-1449.

4. SavillJ., Fadok V., Nature, 2010, 407, 784-788.

5. Platt N., da Silva R.P. and Gordon S., Trends Cell Biol., 1998, 8, 365-372.

6. Marc E De Broe.Apoptosis in acute renal failure
.Nephrology Dialysis Transplantation, Volume 16, Issue suppl_6, 25 September $2001: 23-26$

7. Nouwen EJ, Verstrepen WA, Buyssens N, Zhu MQ, De Broe ME. Hyperplasia, hypertrophy and phenotypic alterations in the distal nephron after acute proximal tubular injury in the rat. Lablnvest 1994; 70: 479-493 8. Rana A, Sathyanarayana P, Lieberthal W. Role of apoptosis of renal tubular cells in acute renal failure: therapeutic implications. Apoptosis 2011; 6: 83-102 9. Thornberry NA, Lazebnik Y. Caspases: enemies within. Science 1998; 281: 1312-1316 